\title{
Colonial vs Colonized Counter-Hegemonies: Two Vistas of Moroccan Educational Models
}

\author{
Driss Bouyahya \\ Moulay Ismail University, Morocco \\ dbouyahya@yahoo.com
}

DOI: http://doi.org/ 10.36892/ijlls.v2i4.423

\begin{tabular}{|c|c|}
\hline $\begin{array}{l}\text { Received: } \\
\text { 01/11/2020 }\end{array}$ & $\begin{array}{l}\text { Abstract } \\
\text { Both France and Spain used schooling as a vehicle in service of colonization }\end{array}$ \\
\hline $\begin{array}{l}\text { Accepted: } \\
15 / 12 / 2020\end{array}$ & $\begin{array}{l}\text { during the Protectorate era in Morocco, whereas Moroccans retaliated with } \\
\text { counter-hegemonic tools to resist and interrogate imposed educational models } \\
\text { in order to implement their oppositional agendas. Thus, the paper is threefold: } \\
\text { it attempts to revisit and sketch out both colonial policies in education with }\end{array}$ \\
\hline $\begin{array}{l}\text { Keywords: } \\
\text { Franco-Berber schools, } \\
\text { Free schools, } \\
\text { French/Spanish } \\
\text { Protectorate } \\
\text { Hegemony, Moroccan } \\
\text { elites, Spanish-Arab } \\
\text { schools. }\end{array}$ & $\begin{array}{l}\text { their ramifications, while outlining and analyzing their strengths and } \\
\text { limitations. The study also seeks to investigate how Moroccans establish } \\
\text { resistance movements to react to the newly-imposed colonial hegemonies, } \\
\text { such as free schools and reformed traditional Qur'anic schools (Msids), } \\
\text { discussing their goals, structures, success and failure. Finally, the paper } \\
\text { explores colonial education as a site of interaction or "contact zones" } \\
\text { between French and Spanish colonizers and elite Moroccan Muslims and } \\
\text { Nationalists who sought to counter the processes of acculturation, } \\
\text { marginalization and subalternization. The study covers the Moroccan } \\
\text { schooling system from } 1912 \text { to 1956. The study dwelled on the congruity of } \\
\text { education as an ideological apparatus to shape identity and/or dominate in a } \\
\text { battlefield over power between the Protectorate powers and the Moroccan } \\
\text { nationalists, who made use of different discourses as an instrument of power. } \\
\text { This essay unravels some conclusions that both French and Spanish } \\
\text { Protectorates utilized different vistas to establish and sustain their } \\
\text { hegemonies through education and instruction, such as Franco-Berber } \\
\text { schools and Spanish-Arab/Spanish-Jewish schools respectively. While, } \\
\text { Moroccan Muslims and nationalists countered the former hegemonies through } \\
\text { creating a free-school system and reforming traditional Qur'anic schools. }\end{array}$ \\
\hline
\end{tabular}

\section{INTRODUCTION}

In order to understand deeply and thoroughly the current educational system in Morocco, it is mandatory to sketch out and excavate the history of that system. For any researcher in the history of education, it is vital to narrate, analyze and discuss any educational system's historical trajectories before delving into it. It is crucial to approach this topic from a perspective that takes discourse as an instrument of power in arranging and molding the society.

This paper displays the importance of education in addressing issues of coloniality and the colonial difference in general with particular reference to French and Spanish Protectorate policies. Besides, this paper concentrates on the congruity of education as an ideological apparatus to shape identity and/or dominate in a battlefield over power between 
the Protectorate powers and Moroccan Muslim elites and nationalists who sought to counter the processes of acculturation, marginalization and subalternization. Some central points encompass how education influences the shaping of colonialism's educational ideologies.

Understanding colonialism and its policies can aid in demystifying and reckoning on the contemporary world's societies and decision-making (McNeil, 2005). I guess discussing colonialism is a complex and subtle endeavor because its relational features should be discussed within historical dynamics that are constituted by relations of hegemony and subordination where trenchant forces interact in a contact zone (Pratt, 1991). This is exactly here where the coloniality of power is at work, wherein cognizance geopolitics prevents it to spring in loci other than power centers (Mignolo, 2003; Walsh, 2003).

As soon as the protectorate powers (France and Spain) were officially recognized over Morocco as a result of the treaty in 1912, they reacted hastily to consolidate their territorial hegemonies. Both France and Spain used schooling as a vehicle of colonization during the Protectorate era in Morocco. The colonial powers deemed education as a pillar of colonial policy, whereas Moroccans retaliated with counter-hegemonic tools to resist and interrogate imposed educational models in order to implement their oppositional agendas. Both French and Spanish Protectorates utilized different vistas to establish and sustain their hegemonies through education with the establishment of institutions such as Franco-Berber schools and Spanish-Arab/Spanish-Jewish schools respectively.

This paper aims at contributing substantially in and adding another brick to the literature in the fields of history of education and colonial studies because it is conducted from within by a local researcher. Thus, the paper is threefold. First, it attempts to revisit and sketch out both colonial policies in education with their ramifications, while outlining and analyzing their strengths and limitations. Second, the study seeks to investigate how Moroccans establish resistance movements to react to the newly-imposed colonial hegemonies, such as free schools and reformed traditional Qur'anic schools (Msids). In addition, it discusses Moroccans' goals, structures, success and failure. These Moroccan schooling institutions will be dealt with within from 1912 through 1956.

\section{French Protectorate Educational Policy}

French education during the Protectorate of Morocco (1912-1956) performed a crucial role in fostering the colonial agenda in the North Africa countries (Morocco, Algeria and Tunisia). Part of the colonial educational institutions' role includes disseminating French colonial cultural hegemony across the colonized societies (Irbouh, 2001). Since the French colonial administration assessed traditional Moroccan schools as backward and undeveloped, they established their own in order to enact their hegemony through education as a state ideology apparatus in Morocco during the early periods of the Protectorate. Colonial education served as a vehicle to circulate ideas of republicanism, liberalism and socialism, while intentionally advocating an essentialist and anti-liberal discourse of cultural split or separation. In the same vein, since the outset of the Protectorate, the French colonial powers set up a network of schools for Moroccan Muslims tailored to further their (French) agendas (Segalla, 2006).

The colonial schools were meant to appease conflicts through the consent of the colonized. As stated by Gramsci (1971), consent is one of the main pillars of sustaining hegemony. Nevertheless, the colonial schooling system was a battle field wherein both colonial authorities and Moroccan Muslims and nationalists interact. Accordingly, this policy allowed Marshal Lyautey - the first general resident of the French protectorate period in Morocco - to favor colonial power over Moroccan society through consensus rather than corrosion; in the meantime, he claimed his respect to local ways of life. This illustrates well the Lyautean paragon of peaceful colonization (Colliez, 1930). 
Thanks to his experience in Algeria, he postulated that in Morocco French colonial policies should no more build new schools but renovate older ones. During this era, the colonial powers designed an array of educational offerings for various Moroccan ethnic groups because they wanted to sustain the social order that had been in the pre- Protectorate Morocco. In other words, the Protectorate built schools that reflected the status of each Moroccan social group, by offering each a different type of schooling adequate to a particular social role. Hence, the schools were used as a stepping stone in the colonial hierarchy.

The French colonial administration harnessed its most powerful hegemony through education. Though the true goals of the entire colonial exploitation were disguised, the French Protectorate concealed the reality of the colonial exploitation and claimed "its mission in Morocco as of altruism" (Irbouh, 2001, p.11). In this regards, the colonial administration controlled schools through an array of strategies, such as hiring an armada of subalterns more for their allegiance than for their prowess. Nonetheless, since the outset of the French colonialism, Lyautey showed a great respect to the local traditions; thus, in schooling, he created special educational streams adapted to suit Moroccans' needs in tandem with the Protectorate priorities. To achieve this target, Lyautey trained and educated the elites whom he relied on to spread the French control. The French schooling paradigm in Morocco outsmarted the control zone with shrewdness and tactful measures since the system was tailored to encompass both the Moroccans' identity and culture and the French educational agenda. In this respect, there were two language policies. For instance, subjects such as: grammar, literature, prosody, eloquence and theology were taught in Arabic; whereas the other subjects, such as: math, physics, geography, history and natural sciences were instructed through French. At that period, the French created two types of schools: in the primary education, they opened schools for the elites' offsprings while in the secondary schooling, they created "colleges Franco-Muslmans" (The French-Muslim middle schools), which were founded since 1915 in Fes and Rabat (Knibeihler, 1994).

However, the French Protectorate deemed its agenda's implementation as a bit slow; hence, they were in a dire need to rectify the curricula in Middle schools. Since 1930, new streams that led to baccalaureate diplomat were created, and new subjects were introduced into the curriculum, such as Latin. Afterwards, some Moroccans were allowed to enroll in French high schools after an entrance exam. The French also turned down requests to allot more time to Arabic in their schools, and they explicitly strove to protect the Berbers from too much Islamic and Arabic influence. Moreover, the French policy grew in part out to the belief that the Berbers were of a distinct race from the Moroccan Arabs (Berque, 1940, p. 19). The colonial authorities had very negative attitudes towards Islam (Irbouh, 2001). However, Lyautey, the Resident General of the French zone of the Moroccan Protectorate usually cherished Islam and the Moroccan Muslim culture.

The Protectorate policy sought above all to "produce" young Berbers totally devoted to France, who would obediently serve as intermediaries between the administration and rural populations as well as occupy subordinate positions in the Protectorate bureaucracy. The policy of the Protectorate ends in dissociating ethnic and sociological groups from the rest of society. It establishes a Berber school system apart, and it sets its goals because it was supposed to help the Protectorate administration to implement Berber policy. This reductive view of Moroccans is roughly analogous to subjective economics of thought, or a utility theory 1 that seeks unity through marginalization of the others. In other words, it seeks to improve Berber agriculture and keep them distant legally, politically, linguistically and

\footnotetext{
${ }^{1}$ This term refers a theory that, instead of discarding its Others, employs them in order to further distinguish itself (i.e. in opposition to them) Such theories, therefore, work by utilizing their Others in the service of selfdefinition.
} 
religiously keep the mountainous tribes from the religious orthodoxy of the Arabic speakers in the plains.

The policy is thus centered on making Berbers administrative clerks and officers in the French army. This is how the administration of the Protectorate devotes a special status for the sons of the local elites of Berber origin. Furthermore, for some authors, it was the "combativeness of the Berbers" observed during the pacification operations that gave birth to the idea of making it a reserve of troops. This "fighting spirit" was, according to these authors, behind the offers made to local chiefs to ensure "a good military career for their sons in the French army" (Waterbury, 1975: 134). However, without utterly dismissing this explanation, we think that it is above all a question of conducting an indigenous policy of social reproduction which consists in preparing the sons of "local elites" to substitute their fathers in command in the tribe.

To disseminate its hegemony, the French authorities started to build French-Berber schools, which were six in 1923 to reach 18 in 1928. This policy was geared to isolating and protecting the Berbers from the Arab influence. The implementation of this policy was the promulgation of the Berber decree on May 16th, 1930. Among the most imminent schools was college Berber d'Azrou which was founded in 1927 and was aimed at instructing the Berber elite's children. The schooling served as a tool for French political penetration into Berber mountainous regions. The French-Berber educational institution had two main goals: the amelioration of Berber farming and the extension of the French as the official language of instruction. Thus, by doing so, the Protectorate separated the Berber legally, religiously, politically and linguistically from the religious orthodoxy of the Arabs in the plains ( Benhlal, 2005).

In this regards, Antoine Prost (1968) argues that the college of Azrou, like any educational institution, cannot be "isolated from the society which generates it and which it contributes to its shaping" (p. 7). The main mission of the educational institution was to socialize; that is to provide an education that made its receptors internalize the value system and the ideology of the dominant class in order to assimilate them, and make the receptors effective intermediaries for the realization of colonial projects. This socialization was an objective of the French Protectorate in Morocco, rather than adopting assimilation.

Penetrated at various levels by the dominant civilization, the colonized societies were subjected to a forced "modernization" operation imposed from the outside. Under pressure from colonizing society, their "traditional" structures fell apart without being able to develop new ones. Anthropologists describe this phenomenon as a process of social "disintegration" and cultural "uprooting" (Bourdieu and Sayad, 1964). On the cultural level, the "traditional" value systems, attitudes and behaviors collapse to make way for a new ethos and new behaviors whose observers have noted the "ambiguous" and/or "incoherent" character. Bourdieu (1964), Fanon $(1975,1961)$ and Memmi (1966) have tried to explain the mechanisms and the results of this acculturation process.

For Joseph Chailley-Bert, a colonial thinker who inspired Lyautey a great deal, the concept of Protectorate implies two things: protection and education. Among the aspects of this protection was the safeguarding of the interests of the natives even against the Europeans. But it also included the maintenance of traditional institutions and hierarchies. This respect for the essential foundations of indigenous society implies, precisely, education. It is it which must assure the traditional elites the capacity essential to the continuation of their previous action under the new conditions imposed by the colonial regime. In this perspective, a distinction must be made between the education given to the children of lay people and that reserved for the children of the aristocracy.

European education is characterized by ethnic segregation on the one hand, (Europeans, Israelite Moroccans, Muslim Moroccans), and social segregation on the other 
(sons of notables on one side, plebs of the other). The distinction is very clear between children from the ruling classes - the main support of the residence - and children from the urban plebs - who "speak Arabic and are steeped in Islamic tradition". Two types of schools were thus experimented in these Berber regions: makeshift schools (which in fact depended on the local military authority) and regular schools (designed according to the model of rural schools, as defined in the circular of the Director of Education dated August 30, 1920). In a note given to Marshal Lyautey by the director of public education February 9, 1925, it was estimated that, for budgetary reasons, these rural schools "will unfortunately be done only very gradually and will remain very limited for a long time".

In fact, if the curricula differ, the goals of Berber schools were to achieve was always the same. It was above all, as specified in a note dated June 25, 1924 to the heads of the regions of Fez, Marrakech and Meknes, to provide young Berbers with practical agricultural education, useful notions of calculation, a little hygiene, basic French, possibly reading and writing Berber. In 1914, attempts were made to give special training to teachers called upon to teach in Berber schools by having them follow courses of a Berber study center in Meknes (Gaudefroy, 1928: 119).

Berber schools were, therefore, placed under the direct control of the native affairs officer. The school system based on the use of French also tended to form auxiliaries to a policy of Berber regionalism, the characteristics of which asserted themselves clearly enough to inspire the most explicit precautionary advice to specialists in native matters. Therefore, it "seems that we must not let ourselves go to this utopia of the Berber who is not a Muslim, to build systems which after all can only create us more embarrassment than anything else" (Michaux, 1927: 268).

The French- Berber schools must first teach French and use it as the language of instruction; they will give young schoolchildren a set of simple and practical concepts that can be classified under the heading of usual knowledge. The French-Berber schools' curricula, whose detailed program will be easy to define and may vary depending on the region, will include some elements of calculation, local geography, agriculture, livestock, gardening, hygiene and a thousand little knowledge. These are the content courses. French will be the basis of all education given in Franco-Berber schools. This does not mean that it was not desirable for the teachers to know the Berber dialect spoken in the region where their schools will be located. Their action on the populations will be deeper if they can express themselves without intermediary with them. However, College Berber d'Azrou gathered the wrath of the nationalists, who dreaded the Berbers' Siba (dissidence) and claimed schooling for every single Moroccan. Hence, this institution became the realm of Arabization (Jobert, 1985).

On the other hand, the French Protectorate established vocational schools to train students on local artifacts and handicraft which was related to the indigenous schooling. For instance, the vocational school of Sefrou sought to make Moroccan trainees familiar with economic development of their country for them to earn dissent salaries without arousing their critical and assertive spirit. In the vocational school of Sefrou, there were several sections, but the agricultural one was the most successful.

The French educational system during the Protectorate in Morocco played a vital role in reinforcing and/or implementing the colonial agenda. It was based on the policy of, "dividi et empera" (divide to rule). This policy was well-orchestrated because it sought to adopt both social and ethnic segregation. In addition, schooling in the French colonial system was one of the main points of contact between colonizing and colonized societies. Its task was to create an "advanced elite" that can act as an intermediary between the colonial administration and the indigenous populations. 


\section{The Spanish Paradigm}

The role of the colonial schools seems to be ambivalent because they do not only serve as a power instrument so as to discipline the populace and exploit the small number of elites who serve to manage the administrative routines, but also offer one of the vistas to question the colonial powers. The Spanish authority has designed and implemented schooling policy as a part and parcel of a wider strategy of establishing a colonizer-friendly elite that could assist the Spanish colonial hegemony in the North Protectorate region.

If we scrutinize the Spanish education policies during the early years of the protectorate, we observe several diverging suggestions and policies for the indigenous education in the North of Morocco. For instance, the model of Spanish-Arab schools, which combined European pedagogy, teaching Spanish language and culture and Arabic, prevailed, yet it sought to improve the Qur'anic education system. This dilemma and/or dualism made the authorities in charge of educational affairs torn between different paradigms (Gonzalez, Gonzalez, 2008). While the Qur'anic education was under the "Houbous" control (pious foundations) by the khalifa (the local power representing the Moroccan Sultan in the North), the Spanish-Arab schools were run by the local Spanish administration. In addition, the Spanish-Israelite and Spanish schools were administered by the central authorities from Madrid.

The Spanish educational policy which was a colonial ideology state apparatus (Althusser, 1971), consist of threefold. First, it was an instrument of surveillance sought to control the populace so that the colonial powers would get access to information on what was circulating among autochthones'. The other was building schools in urban areas, geostrategic zones and cross roads or souks (weekly open-air markets) was mean to control the territories. Third, the Spanish educational system targeted instructing a pro- Spain elite to serve in its local administrations. The Spanish- Arab schooling system had just aped the French one in Algeria to implement it in Morocco.

Spanish colonial powers set up an educational policy in the North of Morocco, which nudged the coexistence among different schooling systems; each of which targeted a specific population according not only to the religious communities, be they catholic, Muslim or Jewish but also to the social status. During the Spanish Protectorate, each of those schools had an ideological agenda (Gonzalez, Gonzalez, 2005). Accordingly, there were three types of schools: the colonial, the nationalist and the traditional. Being savvy of the pertinent social role of education, the Spanish colonial authorities used education to reinforce an utterly colonial system wherein the language of instruction is Spanish; meanwhile the colonial culture was the focal target to be disseminated and strengthen its hegemony. In addition, the Spanish schooling system in Morocco served the target of 'peaceful penetration' by educating the people of the frontier (Francisco, Sempere, 1905). The early schools were geared to both Spanish and some Moroccans (note-worthy figures). The latter were trained and instructed so as to be in the service of the colonial institutions as future translators, interpreters or personnel assistants (Gonzalez, Gonzalez, 2005). The Spanish educational policy utilized multifarious instruments to dominate the pluralistic make-up of Moroccan identities. For instance, there was a large spectrum of educational institutions, such as Spanish schools, public, Spanish-Arab and Spanish-Hebrew schools. This case is similar to the regions under the French Protectorate where there were French schools subsidized by the French alliance (Chaubet, 2006), French-Arab schools and Universal Israelite Alliance centers (Kaspi, 2010).

The Spanish-Arab and Spanish-Hebrew schools were pretty much similar. While the former were open for the Moroccan Muslim, the latter welcomed Moroccan students from the Judaism creed. They were mainly located in three cities, Tetouan, Larache and Asilah. However, in 1935 the Hebrew-Spanish centers were within the Spanish schools wherein they became just Hebrew sections (Gonzalez, Gonzalez, 2005). The second type of education was 
the nationalists' schools2. Their birth was when the nationalist movement vindicated some political and social changes in order to respond to the locals' needs. Besides this, in order to counter the colonial hegemony, some nationalists, such as Adbessalam Bennouna and Mohamed Daud inaugurated the first nationalist school in Tetouan in 1925 under the name of "Ahlia" (The qualification). This institution adopted European educational curricula where the Morocco history, geography and literature were allotted a special status. The nationalist schools also used Arabic as the official language of instruction unlike the Protectorate schools (Gonzalez, Gonzalez, 2005) which relied on its mother tongue (Spanish) as the official language for teaching. In those nationalist schools, students from middle class background got scholarships thanks to the high Moroccan commissioner since 1937 to pursue their studies either in Spain, Egypt or Nublous (Gonzalez \& Azaola, 2008).

The third school model was the traditional schooling that took place in Qur'anic schools (Msid) for Muslims and in the Talmudic schools for the Jews. This type of schools had always been the dominant and remained intact for centuries in Morocco. Furthermore, it was based on religious education through teaching Qur'an and Talmud and teaching Arabic and Hebrew respectively. There were two authorizes at the helm of the two institutions, Qur'anic and Talmudic schools, the Ministry of Islamic affairs and the Grand Rabbi respectively.

During the Spanish Protectorate in the North of Morocco, schools were constructed as a completing vehicle to foster the political and military control. The colonial power's ultimate target was threefold: reinforcing the territory control, counter-attacking the local resistance to the colonial hegemony and finally training a population that could endorse its colonial ideology.

Four major chronological have been singled out for mention to delineate the construction process of the Spanish-Arabic schools during the Spanish Protectorate. The first era occurred between 1912 and 1916 wherein the colonial authority built schools mainly in urban areas. These cities were either in the commercial and mining agglomerations or in the newly-created schools in the Eastern part by the Spanish colonial powers for military purposes, such as Nador (Aziza, 2003). The second phase was between 1916 and 1927 when the Spanish army managed to control all the regions under its Protectorate. The number of schools escalated rapidly to cover several rural areas, mainly into different tribes. The teaching staff encompassed teachers, army officers and military priests; besides, there was not any specific teaching curriculum because the instructors, who taught reading, writing, fundamental Math basics and basic notions on Spanish history and geography, relied merely on improvisation (Gonzalez, 2005). The third period stretched between 1927 to 1936 - when the Spanish administration constructed more schools that covered more than sixty different localities. Nevertheless, this type of schooling was very elitist since it was entirely aimed at special people.

The last phase was the Franco period. With the coming of General Francisco Franco Bahamonde at the helm of the Spanish authority (1939 to 1975), there were numerous reshufflings with the colonial education system in morocco through reinforcing and restructuring the Spanish-Arab schooling and introducing Islamic teaching in those schools. Those measures were meant to establish a balance between the local identity and the colonial agenda, and thus achieve consent with the Moroccan Nationalist Movement and satisfy the Spanish residents of the Protectorate. Besides, General Franco wanted to thank and collaborate with the former who supported him during the Spanish Civil War. Franco's educational policy in Morocco pleaded for a cultural and educational development of the region, based in Spanish-Arab fraternity (Mateo, Dieste, 2007).

${ }^{2}$ These types of schools will be dealt with thoroughly under the free schools in the Arabic Education. 
The educational modeling orchestrated by Franco's regime was designed to the "Moroccanization" of the educational sector through recruiting Moroccan teachers. In 1937, the Spanish High Commission proceeded into redeployment of Spanish-Arab schools to turn them into Moroccan institutions (Gonzalez, Gonzalez, 2005). The rearrangement was in the form not in the content. In other words, the change in the labelling was a pretext for the Spanish to pledge openly their recognition towards the Moroccan National identity which is centered around linguistic and religious tenets and priorities. Hence, there was a shift from a Spanish colonial system to a national model where Arabic is the vernacular educational language, and Islam is the basis for religious education. In addition, the Spanish teaching staff was substituted gradually by Moroccan instructors in that these latter would be in charge of teaching all subjects, whereas Spanish would be taught by the Spanish.

These schools were run by Moroccan headmasters assisted by a Spanish counselor. This latter was in charge of the whole administrative chores and the curriculum implementation (Gonzalez, Gonzalez, 2005). Headmasters were the vehicles through which the high commission controlled these schools, and teaching staff were mainly Moroccan teachers. In 1948, Muslim primary education witnessed new reforms. For instance, the instruction time increased by 3 hours to reach 33 hours per week. Both Arabic and Spanish were used as languages of instruction in these school with 10-hour class and 6 hours weekly, respectively. The shift towards a traditionalist paradigm to schooling in the helm of language and religion reached its zenith with the Civil War outburst in 1936. During this era, the rebel nationalist government enacted the Arabization policy of Moroccan Muslim schools which extended till the offset of the Protectorate (Figueras, Garcia, 1944).

On the overall, throughout the Spanish Protectorate, the colonial powers had established and sustained its own schooling system that geared towards Moroccan Muslim populace. For instance, the Spanish-Arab archetype, also called the "Moroccan Muslim" during Franco era, epitomized an exemplary educational system, which was a synergy between European Modernity and the appreciation of Moroccan tradition and identity. As mentioned above, in those schools the Spanish trained a pro-Spanish elite who were supposed to be obedient to and employed by the colonial authority in order to solidify its control over the country, mainly on those areas deemed strategic or rebellious. During Franco's era, the educational policy in the North of Morocco was very symbolic since its ultimate target was to found a common ground with the Nationalists and satisfy their vindications. In fact, all those so called reforms were just a sham that the Franco's regime sought to disseminate a glamorous image on the international scene, mainly the Arab world.

\section{The Moroccan Educational Counter-hegemonic Policy}

Prior to colonial conquest, education played a crucial role in the Moroccan society as a vehicle of cultural endeavors and cultural capital which determined an individual' social status. In fact, Morocco had a traditional education system based on Islam. Students used to go to Qur'anic schools (msid) and Qur'anic secondary schools (madrasa). The main component in these schools' curriculum was the memorization of the Quran and basic literacy (Ennaji, 2005). At this era, Arabic was a privileged and dominant language in teaching religion, literature, history and sciences. In other words, the first Moroccan school system was rooted in the Islamic tradition and because of the intrinsic link between Islam and Arabic, the language of instruction was naturally Arabic. In this traditional schooling system, there were 3 levels of instruction: the Msid, the Madrassa and Qarawiyyine University. The Msid was part of the primary education where the kids were taught how to read, write and memorize the Qur'an. In fact, the curriculum zeroed in on reciting the Qur'an through memorization without even thoroughly understanding its meaning. This educational paradigm eschewed any recreation activities, such as songs, games and sport. In addition, the dominant 
educational tradition deterred any room for debate, but fostered memorization. Afterwards, the students joined the Madrassa wherein they are introduced to new subjects, such as theology, grammar and law. Finally, some of the eminent students or sons of the elite would join the Qarawiyyine University in Fes to pursue their studies in mathematics, grammar, law, medicine and logic.

During the 1900 s, there were 100,000 out of 800,000 students of schooling age who used to attend the Qur'anic schools (Knibiehler, 1994, p. 490). This fact did not yield to the colonial authority because some Moroccan pious elites have foisted those Qur'anic schools with revised and reformed syllabi and teaching methods, such as reinforcing a better Arabic teaching. In fact, it was difficult to undertake this renovation (Spillmann, 1937). Nevertheless, between 1920 to 1940, the Moroccan education gurus approached this refurbishment positively.

In the early colonial periods, most Moroccans were suspicious of any education that deviated from the traditional schools, namely French- Muslim and Spanish- Arab schools (Segalla, 2006; Gonzalez, 2005). The elites regarded these French and Spanish schools as a hazard to the Arabic Muslim identity since they both taught Moroccans the local catholic doctrines which would lead them astray from the right path of Islam. To counter both French and Spanish colonial hegemony, Moroccan nationalists established private free schools (almadaris al-hurra), whose main language of instruction was Arabic.

The first free schools were established in 1919. The founders, who "shared the same experience of colonization by an alien power" (Damis, 1975, p.78), reacted to the overrunning of a foreign ruler; in other words, through the founding of those free schools, they resisted the newly-imposed colonial hegemony. During the early times of the Protectorate, there was a resentment against the colonial presence because the French posed a serious cultural menace. This threat originated mainly from the gradual settlement of a French-oriented public school system.

The deep opposition between the European school and the traditional school was manifested by the reluctance of the Moroccan population still attentive to Qur'anic fqihs. The European school was criticized for not reserving the place deserved in the teaching of the Arabic language and Islamic subjects. Attendance at school was also hampered by the concern of many parents to prevent their children from spreading the contagion of Christian proselytism of which the latter would be the instrument and this was understandable.

Prior to the Western Protectorate and for hundreds years, Moroccans have adopted religious attitudes to life since as they had been deeply-rooted into a broad Islamic society that shaped their identities. At the same time, their identity was tied up to Arabic (be it literary or colloquial) because Arabic was the language of Islam and of tacit traditional education. Besides, since the colonial schooling system was an indirect ultimatum to Islam as a creed system and a blunt defiance to Islamic culture and Arabic language, free schools were built to save the Arabic language and Moroccan identity. In other words, from the outset, the colonial powers (mainly French) opened a few schools as a vehicle to disseminate both their culture and language. In this context, Moroccans reacted to reform Qur'anic teaching in Msids as the colonial school did not cater for a genuine and thorough instruction of the Arabic language. Moroccans' retaliation was meant to upgrade the "nature and quality of traditional learning by creating a new form of educational institution" (Damis, p.80). The free schools' settlement was the outcome of an action-reaction battlefield to sustain Moroccan identity (language and religion). Free schools were to reform and modernize the Msids. They were the seeds to upgrade the educational system and compete with the Protectorate. However, unless the Protectorate had set up a modern school system in Morocco, free schools would not have existed as the reversed colonialism had made pressure on the locals to 
innovate and improve their orthodox educational institutions in terms of space, curricula and philosophy.

The early free schools epitomized the founders' patriotism in defense of their faith and language. For instance, Darb La'lu school, created in1921, was founded as a patriotic Islamic school to reinforce a sense of religious and cultural patriotism (Kenneth, 1972) whose pioneer founders came from different walks of life. According to Damis's typology (1975), the schools can fall into 4 main categories: Salafists, traders, Sufi orders' members and fqihs. To avoid any polemics over this typology, important to clarify these individuals' overlap. For instance, Ulama were also involved in trade, while Salafists, merchants, Ulama and fqihs may all pertain to a religious brotherhood. These groups were defined by ideological orientations, level of education and occupation. On the overall, the founders were motivated by a desire to keep Moroccan children out of the Protectorate schools in order that they would preserve their genuine Arab and Muslim identities (Marty, 1925).

During the 1920s, one of the distinctive features between a free school and a traditional Qur'anic school was the curriculum and the teaching methods. Free schools departed relatively from the modernization of the curriculum in the Msids. For instance, beside Qur'an memorization, new subjects such as basic tenets of Islam, Arabic grammar, and a little arithmetic were incorporated. Nevertheless, a few schools' curriculum encompassed history, geography, logic and basic French (Marty, 1925, p. 140). Some others offered a fairly utter modern elementary curriculum. For example, the Naciriyya school in Fes implemented a broader curriculum that included four major components: Qur'an (its recitation, writing and pronunciation); Religion (Islamic jurisprudence, Prophetic tradition, and the prophet's life; Arabic (grammar/conjugation, vocabulary, rhetoric and composition); and complementary courses (ethics, arithmetic, history and geography) (Damis, 1975).

Another differentiating trait was the teaching methods. Unlike the single class of Msid, in the free schools, students were split into classes according to their level and progress. In addition, students with similar abilities were assigned to learn the same Qur'anic passages. This methodology was an avant-garde because it customized learning and responded to the learners' abilities according to age and level of achievement. In addition, in free schools, explanation gained prominence over memorization. While a vast majority of students at the early free schools originated from upper-class or rich families, a minority of students were sent to French schools, which were mainly for the sons of the upper-class and Makhzan families. On the overall, parents opted for free schools because they accused the colonial schools for leading their children to abandon their Muslim identity.

Free schools' ultimate targets oscillated between ideological orientations (identity) and pragmatism. First, the founders aimed at solidifying the Arab-Islamic cultural tradition (Thurath). Second, they sought to immune Moroccan youth against the Protectorate Ideology. Third, their pragmatism was mainly translated into incorporating subjects to respond to the job market requirements. Finally, the "founding fathers" targeted inculcating a national spirit among the students (Damis, 1975, p. 91).

Since 1925, the nationalists have strived to install and adopt a modern educational model in Arabic but tailored according to other schooling systems, such as the Middle Eastern and European. Their ambition grew fonder to build a secondary education institution under the name of the Free Institute of Tetouan (Maahad al Hurr) (Gonzalez, Gonzalez, 2005). With this milestone institution, the nationalists aspired to allow Moroccan students to study in Morocco without bothering to move to the Middle East, Egypt, Nablus or Spain in order to pursue their tertiary education.

The first free schools were not that strong at the outset 1919-1929. However, in the early 1930s, new free Muslim schools started to mushroom in Sale, Fes and Rabat (Benhlal, 2005). This type of schooling was modern and bilingual. Although Moroccans had to follow 
the ancestral conditions of Qur'anic schools, free schools had witnessed a great success. They were also labelled the "renovated-masjid-private schools so as to counter the Protectorate policies and regulations, such as the Berber Dahir in 1930.

In a nutshell, the first Free schools' establishment was a part and parcel of a wider cultural reaction to colonial hegemony, mainly to the French-oriented public school system. In other words, those schools' activities to counter the colonial dominance were geared towards cultural rather than political reforms. Meanwhile, they were encouraged to react to the colonial power's effort at cultural assimilation. Accordingly, the free schools of the 1920s had few political agendas. However, after 1930, and mainly 1944, free schools were an integral part of the development of the Moroccan nationalist movement.

\section{CONCLUSION}

One of the findings of this essay is that several authors have shown how the colonial education system tends to socialize colonized children at dependence (Bourdieu and Sayad, 1964; Colonna, 1975; Jabri, 1974; Sraïeb, 1971). Also, this study highlights the emphasis that is placed on the "acculturation" aspect of school, defined as "dependency socialization" say which consists of making colonized children recognize and accept the settler's subsystem, not only as different from theirs, but also as superior to it. Besides, it uncovers that the "evolved" produced by this educational system, then, tends to overvalue the culture of the colonizer and to devalue their own.

Another finding, in this regard, is that both Spanish and French colonialism adopted slightly similar educational policies in Morocco. Both colonial powers had not schemed or maneuvered separately but had constant conspiracy to have an upper hand in monopolizing and controlling the country (Laskier, 1983). While Spain favored Arabic language and culture to counter the Amazighs (Berber) in the Rif region where they encountered a harsh resistance, the French opted for the Amazighs to spread their hegemony against Pan-Arab nationalism. It is assumed that the Berber Dahir was a pure incarnation of the French policy to spread its hegemony. On the other hand, Franco's regime had a better understanding of the local mindset and needs. Hence, it responded to the nationalists' agenda to gain hegemony which is an agreed-upon consensus. This is a similar scenario to the British policy during its "Empire of the Sun". Accordingly, there was a regular exchange of expertise, experiences and policies between the French and Spanish authorities to facilitate and spread their hegemonies. The Moroccan resistance to the Protectorate has impacted and molded the ideas and policies of the school system, whereas the colonial powers' ideas and policies shaped the strategies and the discourse of the anti-colonial resistance.

However, the study concludes that colonial education was superimposed on another education system which had the privilege of existing before it and, in some cases, has a considerable impact on the society. Hence, a situation of conflict, of struggle, of "confrontation" between two education systems, supports and instruments of two opposing cultures. The history of colonial education is undeniably marked by this conflict. It is this conflicting dynamic that explains the evolution of the colonial education system during the period of colonization. To understand this evolution, the analysis must be centered at the same time on the point of view of the colonizer and that of the colonized.

The education history in Morocco is a hefty terrain for investigation, scrutiny and academic research. Thus, it is mandatory to open new research vistas, and proceed to methodological excavations. These academic projects will dwell on different academic institutions that have a stake into digging up the unspoken and interrogate the outspoken about the history of education in Morocco. It is an urgent call for the academia from ethnography, sociology, history, colonial/post-colonial studies and pedagogy to endeavor in 
order to comprehend the diversity of cultures as well as the affluence of their encounter in the contact zone.

\section{REFERENCES}

Althusser, L. (1971). Lenin \& Philosophy \& other essays. London: New Left Books.

Aziza, M. (2003). La sociedad rifeña frente al Protectorado español de Marruecos (1912-1956). Barcelona: ediciones Bellaterra.

Benhlal, M. (2005). Le Collège d'Azrou: la formation d'une élite berbère civile et militaire au Maroc. Paris: Éditions Karthala.

Berque, J. (1940). Deux ans d'action artisanal a Fès. Paris: Librairie Recueil.

Bourdieu, P. et Sayad, A. (1964). Le Déracinement. Paris: Édition Le Minuit.

Chaubet, F. (2006). La politique culturelle Française et la diplomatie de la langue, L'Alliance Française (1883-1940). Paris: L’Harmattan

Colliez, A. (1930). Notre Protectorat Marocain. La première étape 1912-1930, Paris: Librairie des Sciences politiques et Sociales.

Colonna, F. (1975). Instituteurs algériens 1883-1939. Paris: Presses de la Fondation Nationale des sciences politiques.

Damis, J. (1975). The origins \& Significance of the free school movement in Morocco, 1919-1931. In revue de l’Occident musulman et de la Méditerranée, no. 19

Ennaji, M. (2005). Multilingualism, Cultural Identity \& Education in Morocco. In. A. Rouchdy (Ed.), Language Contact and Language Conflict. (70-88). New York: Routledge Curzon

Fanon, F. (1961). Les Damnés de la terre. Paris: Maspero.

Figueras, T. G. (1944). Marruecos: La acción de España en el Norte de África. Madrid: Ediciones-Fe

---. (1939). Notas sobre el Islam en Marruecos. Larache: Centro de Estudios Marroquí.

Gaudefroy-D, R. (1928). L'Euvre française en matière d'enseignement au Maroc. Paris: Les Presses modernes.

Gonzalez, Gonzalez., I. (2015). Spanish Education in Morocco, 1912-1956: Cultural interactions in a colonial context. Brighton: Sussex Academic Press.

--- (2005). «La política educativa de España en Marruecos (1912-1956). Aproximación aun modelo educativo : La enseñanza hispano-árabe », en Davila, P y Naya, I. M. (eds.). La infancia en la historia : espacios y representaciones. Tomo II, Espacio Universitario Erein, Donosita pp. 700-708

González, I. G.\& Piazza, B. A. (2008). "Becarios marroquíes en El Cairo (1937-1956): una visión de la política cultural del Protectorado español en Marruecos", Awraq Vol. XXV, pp. 159-182.

Gramsci, A. (1971). Selections from the Prison Notes. New York: International 
Hardy, G. (1972). « Discours au Congrès de l'enseignement professionnel indigène» Bulletin de l'enseignement public du Maroc.

Irbouh, H. (2001). "French Colonial Art Education in Morocco“. Art e.journal of African World. Vol. 2, No. 1

Jabri, M. (1974). Éclairages sur le problème de l'enseignement au Maroc (in Arabic) Casablanca: Éditions Maghrébines.

Jenson, G. (2005). The Peculiarities of "Spanish Morocco": Imperial Ideology and Economic Development. Mediterranean Historical Review, Vol. 20, No 1, pp. 81-102.

Jobert, M. (1985). Maghreb: A l’ombre de ses mains. Albin Michel.

Julien, C.-A. (1978). Le Maroc face aux impérialismes 1415-1956. Paris: Éditions Jeune Afrique.

Kaspi, A. (2010) Histoire de l’Alliance Israelite. De 1860 a nos jours. Paris: Armand.

Kenneth, B. (1972). "The Impact of the Dahir Berber in Sale". In Ernest Gellmer \& Charles Micaud, (eds), Arabs \& Berbers: from Tribe to Nation in North Africa. Lexington: Mass, p.207.

--- (1969). “The Social History of Moroccan Town: Sale, 1830-1930“. Unpublished Ph.D. dissertation, U.C.L.A, pp. 114-115

Leskier, M. (1983). "The Alliance Israelite Universal" and the Jewish Communities of Morocco, 1863-1962. New York: State University New York Press.

Marty, P. (1925). Le Maroc de demain. Paris, pp. 140-141

Dieste, J. L. M. (2007). «El interventor y el Cadi. La política colonial española frente a la justicia marroquí durante el Protectorado de Marruecos (1912-1956)», Hispania. Revista Española de Historia, Vol. LXVII, pp. 643-669.

Mc Neil, M. (2005). Introducción : Postcolonial technoscience. Science as Culture, Vol. 4, n. 2, pp. 105-112.

Memmi, A. (1966). Portrait du colonisé. Paris: Pauvert.

Michaux. B. (1966). «Le Maroc », in Le Rôle extra-militaire de l'armée dans le tiers- monde. Entretiens de Dijon, sous la direction de Léo Hamon, Paris, PUF.

Mingnolo, W. (2003). Historia Locales/diseños globales. Colegialidad. Conocimientos subalternos y pensamiento fronterizo. Madrid: Akal

Pratt, M. L. (1991). Arts of Contact Zone. Profession, pp. 33-40.

Prost, A. (1968). L’Enseignement en France 1800-1967. Paris: A. Colin.

Sraieb, N. (1971). «Enseignement, élites et système de valeur: le Collège Sadiki de Tunis ». Annuaire de l'Afrique du Nord.

Sempere, F. (1905). Escuela de primera enseñanza para moros.

Spillmann, C. (1937). «Les écoles coraniques rénovées au Maroc». Interviews on the evolution of Arab civilization. Mémoire du C.H.E.A.M 
Thompson, E. P. (1967). “Time, Work- Discipline, and Industrial Capitalism, ” Past \& Present 38, pp. 56-97.

Walsh, C. (2003). Las geopolíticas del conocimientos y colonialidad del poder. Entrevista a Walter Mignolo, Polis. Revista Académica Universidad Bolivariana, Vol. 1, n. 4. Retrieved from http://www.revistapolis.cl/4/wal.pdf

Waterbury, J. (1975). Le Commandeur des croyants. La monarchie marocaine et son elite. Paris: PUF.

Wesson, R. G (1967). The Imperial Order. Berkeley: University of California Press, p. iii

\section{$\underline{\text { AUTHOR'S BIO }}$}

Driss Bouyahya, Ph.D is an Associate Professor at School of Arts \& Humanities in Moulay Ismail University, Meknes Morocco. He holds a Ph. D degree in Political Islam and Communication. His fields of interest are Religious Studies, Sociology of Religion, Intercultural Communication, Pedagogy, Cultural Studies, Semiotics and Translation. 